\title{
MINIMALISASI RISIKO USAHA PETANI PADI DI DUSUN WATUGAJAH, KECAMATAN BERGAS, KABUPATEN SEMARANG
}

\section{BUSINESS RISK MINIMIZATION OF RICE FARMERS IN DUSUN WATUGAJAH, BERGAS DISTRIC, SEMARANG REGENCY}

\author{
Ade Teya Trisna Dwi Gundariawanti ${ }^{1)}$ dan Sony Heru Priyanto ${ }^{1)}$ \\ 1) Universitas Kristen Satya Wacana \\ Email: 522014034@student.uksw.edu
}

\begin{abstract}
ABSTRAK
Dalam setiap usahatani selalu ada risiko. Risiko merupakan ketidakpastian dan dapat menimbulkan terjadinya peluang kerugian terhadap pengambilan keputusan. Keberhasilan usahatani sangat bergantung dengan musim. Tujuan dari penelitian ini adalah untuk menggambarkan risiko serta upaya dalam menangani risiko dan menggambarkan harapan petani tentang usahatani padi. Penelitian dilakukan pada bulan Februari-Maret 2018 di Dusun Watugajah, Kecamatan Bergas, Kabupaten Semarang. Menggunakan jenis penelitian kualitatif dan dengan pendekatan deskriptif. Hasil penelitian menunjukkan bahwa terjadi beberapa risiko dalam usahatani padi yaitu risiko produksi, harga, teknologi, dan sosial hukum. Risiko usahatani padi termasuk risiko spekulatif.
\end{abstract}

Kata kunci: alternatif, harapan, risiko, usahatani

\begin{abstract}
In every farm there is always a risk. Risk is uncertainty and can lead to loss opportunities for decision making. The success of farming is very dependent on the season. The purpose of this study is to describe the risks and efforts in dealing with risks and describe farmers' expectations about rice farming. The study was conducted in February-March 2018 in Watugajah Hamlet, Bergas District, Semarang Regency. Using qualitative research and descriptive approach. The results showed that there were several risks in rice farming, namely production risk, price risk, technology risk, and social and legal risk. The risk of rice farming is included in speculative risk. There needs to be an effort to maximize production during the rainy season with varieties that are resistant to water stress.
\end{abstract}

Keywords: alternatives, expectations, farming, risk

\section{PENDAHULUAN}

Usahatani merupakan ilmu yang mempelajari cara petani mengelola faktor produksi (tanah, tenaga kerja, teknologi, pupuk, benih, pestisida)

dengan efektif, efisien dan berkelanjutan untuk menghasilkan 
produk tinggi sehingga pendapatan usaha meningkat (Rahim dkk., 2007).

Dalam setiap usahatani selalu ada risiko yang akan didapatkan. Risiko merupakan ketidakpastian dan dapat menimbulkan terjadinya peluang kerugian terhadap pengambilan keputusan. Keberhasilan usahatani sangat bergantung dengan musim, seperti varietas Unggul jika ditanam di musim penghujan maka akan menghasilkan panen yang maksimal.

Akhir-akhir ini cuaca sulit diprediksi. Perubahan iklim di beberapa tempat dapat mengganggu pertumbuhan tanaman. Masyarakat petani di pedesaan agraris, khususnya pedesaan di pulau Jawa, menjadi salah satu pihak yang dirugikan akibat perubahan iklim. Curah hujan dan kekeringan yang sulit diprediksi menyebabkan kekacauan dan ketidakpastian pada saat musim tanam.

Pada saat hujan yang berlebih maka akan muncul hama contohnya wereng, sedangkan pada musim kemarau banyak tikus. Petani mengalami gagal panen yang diakibatkan oleh serangan hama dan cuaca yang tidak menentu yang menyebabkan banjir serta kekeringan. Ketika sawah tergenang air, tanaman padi akan roboh dan padi terkena lumpur sehingga kemungkinan kecil dapat dipanen. Selain itu saat musim hujan hama wereng pun menyerang tanaman padi. Selain banjir dan hama wereng, kekeringan juga menjadi penyebab menurunnya produksi. Tanaman padi akan kekurangan air sehingga pertumbuhan terhambat dan mati. Hama tikus menyerang ketika keadaan sawah kering. Hal ini yang menjadi keluhan para petani. Petani mengalami ketidakpastian ekonomi yang berdampak pada nafkah yang tidak pasti untuk pemenuhan kehidupan sehari-hari maupun untuk modal penanaman kembali. Petani memandang penurunan produksi merupakan sebuah kejadian yang tak bisa terduga, sehingga tetap giat merawat tanaman padi walau pun hanya sedikit yang bisa dipanen. Walaupun mengalami penurunan produksi, petani tetap menjalankan usaha menanam padi. Petani tidak menyerah hanya karena produksi menurun. Pinjaman uang maupun menjual hasil panen bulan lalu menjadikan keringanan dalam memperoleh modal. Hasil panen yang akan diperoleh dijadikan sebagai pembayaran hutang. Petani yakin bahwa usaha tani padi 
dapat mencukupi kebutuhan seharihari. Petani selalu mempunyai harapan untuk usahataninya. Harapan tersebut didukung dengan berusaha di bidang selain bertanam padi. Salah satu tujuan penelitian ini adalah untuk mengetahui harapan yang ingin dicapai petani dalam berusahatani.

\section{METODE PENELITIAN}

Penelitian dilakukan di Dusun Watugajah, Desa Wringinputih, Kec. Bergas, Kab. Semarang menggunakan jenis penelitian kualitatif dengan pendekatan deskriptif. Pendekatan kualitatif merupakan penelitian yang bersifat atau memiliki karakteristik, bahwa datanya dinyatakan dalam keadaan sewajarnya atau sebagaimana adanya (natural setting) dengan tidak diubah dalam bentuk simbol bilangan. Menurut Nawawi (2005), pendekatan deskriptif dapat diartikan sebagai prosedur pemecahan masalah yang diselidiki, dengan menggambarkan /melukiskan keadaan obyek penelitian berdasakan fakta yang tampak atau sebagaimana adanya. Pengumpulan data dalam penelitian dilakukan dengan langkah sebagai berikut: wawancara mendalam, observasi, dan studi dokumentasi.
Untuk memastikan kebenaran hasil yang diperoleh, digunakan uji keabsahan data dengan teknik trianggulasi, yaitu dengan cara membandingkan hasil teknik observasi, wawancara, dan dokumentasi (dokumen tertulis, arsip, catatan pribadi, dan foto) dari petani dengan ketua kelompok tani yang bertujuan untuk mengecek kebenaran serta memperkuat data penelitian. Analisis dilakukan beberapa tahapan analisis, yaitu: reduksi data, penyajian data, dan penarikan simpulan.

\section{HASIL DAN PEMBAHASAN}

\section{Kelembagaan Petani}

Kelompok Tani Suka Karya 1 merupakan wadah perkumpulan petani di Dusun Watugajah Desa Wringinputih. Anggotanya merupakan masyarakat yang memiliki lahan pertanian maupun tidak, yang pengelolaannya belum maksimal. Kelompok tani terbentuk pada tahun 1985 dengan ketua Pak Mul yang beranggotakan 15-20 orang. Kelompok tani terbentuk berdasarkan program pemerintah dan terdiri dari masyarakat yang mempunyai keakraban dan kepentingan sama. 
Dalam perkembangannya, kelompok Tani Suka Karya 1 melakukan reorganisasi pada tahun 2003 yang diketuai oleh H. Zuri. Hal ini dilakukan untuk memunculkan ide baru. Pada tahun 2011 terjadi pergantian ketua yaitu bapak Amin hingga sekarang. Ketua kelompok tani merupakan kadus di Dusun Watugajah. Karena semua program pemerintah selalu diinformasikan di kantor kelurahan, maka jika ketua tidak berada di kantor, informasi tidak dapat diterima dengan baik.

Satu bulan sekali kelompok tani melakukan pertemuan rutin yang didampingi oleh PPL yang memberi saran mengenai keluhan petani. Banyak kegiatan yang diprogramkan yaitu minatani, kemudian terjadi pemisahan antara pertanian dengan perikanan. Selanjutnya terdapat program pertanian dan peternakan. Banyak yang memanfaatkan peternakan domba karena rumput mudah diperoleh, mengingat terdapat perkebunan karet di lahan sekitar dusun.

Karena penurunan produksi akibat serangan hama tikus maka beberapa petani yang tanah pertaniannya dapat dikeringkan mulai menanam sayur. Hal ini dilakukan untuk menambah penghasilan petani saat terjadi penurunan produksi padi.

Selain mengikuti kelompok tani, petani juga mengikuti program pemerintah yaitu PUAP yang berada di tingkat desa. Jika ada petani yang ingin meminjam uang untuk kebutuhan bertani, maka harus datang langsung ke kantor desa. Cara pengembalian pinjaman brvariasi, dapat dilakukan per minggu, per bulan atau setiap panen. Anggota yang melakukan pembayaran secara rutin akan mendapatkan penghargaan berupa peningkatan jumlah pinjaman. Untuk petani yang sering telat membayar akan dilakukan penagihan secara langsung kepada yang bersangkutan. Jika masih belum bayar juga maka anggota tersebut tidak diberikan pinjaman dan PUAP dapat dihentikan untuk dusun tempat petani tinggal tersebut.

\section{Sumber Daya Alam}

Dusun Watugajah terletak di Kel. Wringinputih, Kec. Bergas, tepatnya di perkebunan karet milik PTPN IX Ngobo, setengah jam dari lereng Gunung Ungaran. Dusun ini mempunyai hawa yang sejuk.Tempat ini cocok untuk berusahatani ternak 
atau tanaman yang tidak

Ketersediaan sumber daya alam membutuhkan hawa dingin.

Mayoritas usahatani di desa ini bertani padi sawah yang terletak di lembah di bawah kebun karet. Di samping lahan sawah terdapat aliran sungai kecil yang dimanfaatkan untuk irigasi sawah yang berasal dari sumber air yang berada di dusun Ngobo. Air ini juga digunakan oleh masyarakat untuk kebutuhan sehari-hari seperti masak dan mencuci. Air dikelola masyarakat desa dan ditampung dalam bak penampung sehingga ketersediaan air tidak dapat dikhawatirkan lagi. Pembagian air untuk irigasi sawah cukup adil sehingga untuk lahan yang paling ujung tetap mendapatkan pasokan air.

Areal sawah berkontur datar datar sehingga tidak membutuhkan terasering. Bagian samping sawah terdapat lahan tegalan dan perkebunan karet. Lahan tegalan dan kebun karet letaknya lebih tinggi dari sawah. Pemilik tahan tegalan ini juga pemilik sawah. Walaupun datar, tidak semua lahan sawah bisa dibajak dengan traktor karena lahan yang paling ujung sangat dalam sehingga lahan harus diolah dengan dicangkul. 
hasil yang didapat dan membandingkan dengan sistem tanam padi yang biasanya secara demonstrasi plot sehingga petani paham dan menerapkan sistem tersebut. Meskipun demikian masih ada petani yang belum bisa menerima pembaharuan. Petani menganggap sistem jajar legowo boros karena banyak lahan yang kosong. Petani belum bisa belajar dari petani lain yang sudah menikmati hasil sistem jajar legowo.

Petani yang mempunyai pendidikan SMP, SMA, dan Perguruan Tinggi dapat menerima masukan dengan dengan baik. Tidak perlu waktu yang lama dalam beradaptasi, mempunyai ketekunan dan keloyalan yang baik dalam bertani. Walaupun produksi berkurang, petani terus melanjutkan usahanya. Ketika padi terserang hama, petani juga melakukan tindakan perlindungan tanaman dengan penyemprotan racun untuk hama.

\section{Risiko Pertanian dan Usaha Petani dalam Menanggulangi}

Menurut Djohanputro

risiko pertanian termasuk risiko spekulatif. Risiko spekulatif adalah risiko yang memberikan kemungkinan untung (gain) atau rugi (loss) atau tidak untung dan tidak rugi (break even). Risiko Spekulatif disebut juga risiko dinamis (dynamic risk).

Ada beberapa hal yang menyebabkan turunnya jumlah produksi. Risiko produksi terjadi karena variasi hasil akibat berbagai faktor yang sulit diduga, seperti cuaca, penyakit, hama, variasi genetik, dan waktu pelaksanaan kegiatan (Tjeppy, 2007).

\section{a. Risiko Produksi}

Pertanian sangat bergantung pada kondisi alam, jika tanaman ditanam pada musim yang cocok maka akan diperoleh hasil maksimal. Ketika kondisi alam mendukung maka hasil panen sesuai dengan yang diharapkan.

Pada musim kemarau, sering kali pasokan air berkurang sehingga kebutuhan untuk tanaman semakin berkurang juga. Hal ini menyebabkan lahan sawah kekeringan. Dari aspek hidrometeorologi kekeringan timbul dan disebabkan oleh berkurangnya curah hujan selama periode tertentu. Dari aspek pertanian, kekeringan dinyatakan jika lengas tanah berkurang sehingga tanaman 
kekurangan air. Lengas tanah (soil moisture) merupakan parameter yang menentukan potensi produksi tanaman. Ketersediaan lengas tanah terkait erat dengan tingkat kesuburan tanah. Secara hidrologi kekeringan ditandai dengan berkurangnya air pada sungai, waduk dan danau (Nalbantis dan Tsakiris, 2008).

Lahan yang kering dapat mengakibatkan datangnya hama tikus. Tikus merusak tanaman dengan mengerat batang dan memakan biji padi hingga habis. Untuk mengurangi populasi tikus, petani menebar racun di areal pinggir sawah secara serempak dan sesekali melakukan gropyokan. Penebaran racun biasanya dilakukan oleh petani yang mempunyai lahan jauh dari perumahan untuk menghindari ternak ayam makan racun tikus.

Di musim penghujan pasokan air berlimpah. Lahan mendapat aliran air dari sumber air dan hujan. Hal ini mengakibatkan lahan sawah tergenang air dan tanaman dapat roboh. Hama pemyakit yang datang pada musim penghujan di antaranya wereng, penggerek batang dan blas.

Secara umum menurut Balai

(2016a) pada musim hujan hama maupun penyakit berkembang lebih pesat dan mengakibatkan kerusakan tanaman lebih parah. Sumber OPT dari musim sebelumnya berkembang dengan intensitas tinggi. Hal ini diduga karena terjadi anomali iklim yang ditunjukkan dengan musim kemarau basah. Dengan kondisi cuaca yang sudah tidak normal, akan secara langsung berdampak pada perubahan perilaku organisme yang berkembang di tanaman padi.

Jika tanaman roboh, biasanya petani akan memanen padi saat masih muda untuk menghindari padi yang tumbuh dalam genangan air, sehingga petani tetap dapat menikmati hasil walaupun tidak maksimal. Kegagalan panen juga berdampak pada penurunan mutu beras. Beras menjadi kusam atau agak hitam serta mudah pecah. Hal ini berpengaruh pada nilai jual, sehingga dikonsumsi sendiri.

\section{b. Risiko Harga}

Ketika persediaan melimpah maka harga beras akan turun dan sebaliknya saat langka harga akan naik. Begitu juga halnya dengan musim yang ekstrim. Pada puncak kemarau harga beras dapat mencapai 
Rp 12.000/ kg, sedangkan pada penghujan harga stabil Rp 7.500- Rp

9.500. Dari perhitungan input dan output produksi, maka biaya yang dikeluarkan lebih banyak daripada hasil yang dipanen petani. Ketidakstabilan harga merupakan salah satu penyebab pasokan beras yang menumpuk maupun terjadinya kelangkaan.

Adanya ketidakstabilan harga dapat mengakibatkan kecurangan di pedagang maupun petani. Hal ini beresiko memunculkan kemungkinan pencampuran beras berkualitas tinggi dengan beras berkualitas rendah demi menghindari kerugian. Belum lagi di tingkat pedagang saat distribusi beras. Pada saat terjadi kelangkaan beras, harga akan cenderung tinggi dan ini justru akan mengakibatkan beras tidak laku karena pembeli tidak dapat membeli dengan harga yang tinggi. Pada saat harga beras murah, petani akan cenderung menimbun beras. Petani tidak akan menjual hasilnya karena dianggap rugi.

\section{c. Risiko Teknologi}

Teknologi pertanian berpengaruh besar pada kualitas dan kuantitas produksi tanaman. Namun perlu diperhitungkan manfaatnya, efektif dan efisien atau tidak di semua daerah, dapat digunakan oleh semua petani atau tidak, berlangsung dalam jangka yang lama atau tidak dan sulit atau tidaknya masyarakat dalam mengambil keputusan dalam mengadopsi teknologi baru.

\section{d. Risiko Sosial dan Hukum}

Karena keterbatasan pemerintah dalam menyediakan subsidi pupuk, maka pupuk bersubsidi hanya diperuntukkan bagi Petani Tanaman Pangan, Peternakan dan Perkebunan Rakyat. Dan untuk menjamin pengadaan dan mencegah terjadinya penyimpangan, maka ditetapkan penyaluran pupuk bersubsidi.

Subsidi pupuk diberikan tiga kali dalam setahun sesuai dengan jadwal tanam. Sedangkan untuk benih tidak ada kepastian pemberian subsidi. Ketidakpastian ini mengakibatkan ketidakpastian pengeluaran petani.

Aplikasi teknologi pertanian sangat penting. Kelambanan petani dalam menerima informasi baru dapat berpengaruh pada pembaruan yang lebih mengguntungkan. Menurut Hernanto (1991) untuk memperkenalkan suatu teknologi baru 
pada suatu usahatani ada empat faktor yang harus diperhatikan, yaitu:

1. Secara teknis dapat dilaksanakan

2. Secara ekonomi menguntungkan

3. Secara sosial dapat diterima

4. Sesuai dengan peraturan pemerintah Petani akan menerapkan teknologi baru jika teknologi tersebut sesuai dengan lingkungan daerah setempat. Teknologi yang tidak rumit lebih mudah diterima oleh masyarakat karena mudah diterapkan. Petani akan menggunakan teknologi ini jika dapat menghemat tenaga dan waktu karena memiliki pekerjaan lain selain berpetani. Teknologi yang tidak memerlukan biaya besar dan menguntungkan akan mudah diterapkan oleh petani.

\section{Alternatif yang Dilakukan Petani Ketika Mengalami Penurunan Produksi}

Gagal panen menjadikan pendapatan petani menurun. Ini memberatkan petani dalam memenuhi kebutuhan sehari-hari dan pengembalian modal untuk penanaman periode selanjutnya. Petani mempunyai beberapa alternatif untuk menutup kekurangan yang ada.

Mengingat lahan yang kecil dan risiko yang mungkin terjadi jika petani hanya mengandalkan pertanian, maka petani tidak hanya bekerja di lahannya, tetapi mempunyai pekerjaan lain yaitu bekerja di pabrik, guru SD, kepala dusun, pengusaha ayam potong maupun sebagai pengusaha lele. Sehingga ketika usahatani sedang tidak baik petani tetap mendapatkan pemasukan. Ketika petani mengalami gagal panen mereka tetap dapat melanjutkan usahanya.

\section{Harapan Mendatang Petani}

Walaupun sering mengalami gagal panen, petani tetap melanjutkan usahanya. Petani selalu mempunyai harapan dalam berusahatani.

a. Produksi meningkat

Meningkatnya produksi merupakan keinginan semua petani yang menjadi informan. Ketika petani memperoleh hasil yang maksimal maka kebutuhan hidup petani dapat tercukupi. Petani tidak perlu membeli beras untuk makan sehari-hari. Ketika panen meningkat biasanya petani akan menjual $25 \%$ dari produksi padinya untuk dijual ke penggilingan padi dengan harga Rp 9.000 - Rp 10.000/kg tanpa melihat jenis berasnya. Jika hal ini berlangsung terus maka kesejahteraan petani akan membaik. 


\section{b. Memanfaatkan lahan untuk tanaman sayur}

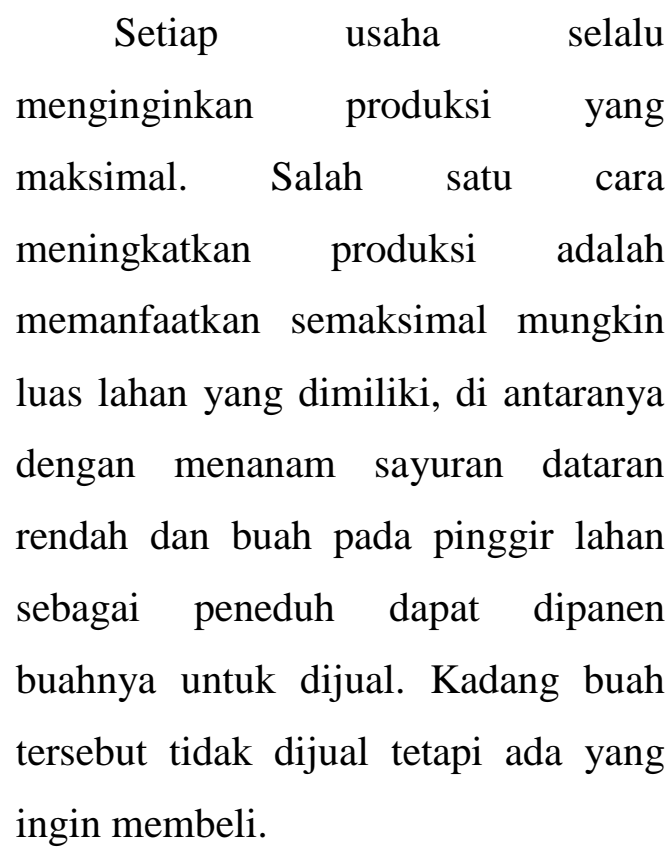

\section{c. Usaha ternak ikan, ayam dan sapi}

$$
\text { Petani menganggap bahwa }
$$

pendapatan dari berternak lebih menguntungkan daripada bertani padi, sehingga ingin mempunyai usaha peternakan dan perikanan. Untuk itu petani membutuhkan kandang untuk ternaknya dan kolam ikan. Pakan ternak dipenuhi dengan merumput di areal kebun karet, sehingga tidak perlu membeli.

Budidaya ikan lele maupun ikan nila tidak perlu menunggu waktu lama untuk panen. Ikan dapat dipanen sebelum petani memanen padi.
Kendalanya, kadang harga pakan ikan mahal.

\section{d. Image petani}

Seperti yang diketahui nasib petani sering digambarkan buruk. Pada majalah anak-anak, petani identik dengan caping dan baju kotor, berbeda dengan pegawai kantor yang berpakaian rapi serta berdasi. Image petani sudah ditanamkan buruk pada diri anak-anak sejak dini. Seharusnya para ilustrator membuat tampilan petani yang lebih baik sehingga menumbuhkan minat anak-anak dalam bidang pertanian karena sudah banyak petani muda yang sukses.

Banyak generasi muda yang lebih memilih bekerja di pabrik yang berangkat pagi pulang petang namun mempunyai gaji yang jelas daripada bertani yang kotor dan hasilnya pun belum jelas. Petani berharap agar pemerintah mempunyai program untuk semua orang yang bertani diangkat menjadi PNS. Harapan ini dimaksudkan agar menumbuhkan minat pemuda dalam bidang pertanian. Mengingat bahwa Indonesia merupakan negara agraris yang sudah semestinya bidang pertanian lebih diunggulkan. 
Usaha Petani untuk Mencapai Harapan yang Diinginkannya

Dalam teori harapan setiap individu percaya bahwa bila seseorang berperilaku dengan cara tertentu, maka akan memperoleh hal tertentu. Hal ini disebut sebuah harapan hasil (outcome expectancy) sebagai penilaian subjektif seseorang atas kemungkinan bahwa suatu hasil tertentu akan muncul dari tindakan orang tersebut (Hubeis dan Vitalaya, 2007). Dalam mencapai harapan, petani harus mempunyai usaha untuk mencapai harapan tersebut. Berikut adalah usaha yang dilakukan petani di Dusun Watugajah.

Petani yang menginginkan hasil produksinya meningkat akan meminimalkan serangan hama dan memaksimalkan upaya yang meningkatkan produksi tanaman, contoh dengan menerapkan sistem tanam jajar legowo (Balai Besar Penelitian Tanaman Padi, 2016b).

Petani sudah mempunyai kolam dengan ukuran kecil untuk konsumsi sendiri atau dijual. Begitu juga dengan ternak ayam, petani sudah mempunyai ternak ayam kampung. Usaha kecil ini jika dilakukan dengan serius dapat menjadi besar dan harapan petani menjadi sejahtera akan tercapai. Sebagian petani sudah menanam sayuran yang cocok pada dataran rendah seperti bayam, kangkung, terong, tomat, cabai.

\section{Cara Mengatasi Risiko Pertanian}

\section{a. Risiko Produksi}

Balitbangtan (2003) merekomendasikan embung untuk mengatasi kekeringan sebagai teknologi penyedia air. Embung adalah kolam besar seperti waduk yang diharapkan dapat terus menyediakan air di musim kemarau. Risiko produksi yang disebabkan karena adanya kekeringan dapat diatasi dengan pembangunan embung. Namun embung tidak bisa menjangkau lahan yang daerahnya lebih tinggi dari embung, sehingga lahan yang di atas embung sebaiknya ditanami tanaman kering seperti jagung, aneka sayur yang cocok di lahan dataran rendah, tembakau. Upaya lain untuk mengatasi musim penghujan yang berkepanjangan, petani harus menanam padi dengan varietas unggul. Varietas unggul mempunyai kelebihan tahan terhadap kondisi cuaca penghujan yang banyak air. 
Menurut Balai Besar Penelitian Tanaman Padi (2017) pestisida merupakan semua zat kimia atau bahan lain serta jazad renik dan virus yang digunakan untuk pengendalian atau mencegah hama atau penyakit yang merusak tanaman, bagian tanaman atau hasil pertanian. Penggunaan pestisida merupakan pilihan utama petani karena menekan serangan OPT. Penggunaan pestisida harus memperhatikan beberapa faktor:

1. Tepat hama sasaran

2. Tepat jenis pestisida

3. Tepat waktu aplikasi pestisida

4. Tepat dosis pestisida

\section{b. Risiko Harga}

Ketidakstabilan harga membuat resah petani maupun pembeli beras. Ketika harga beras murah petani tidak akan menjual hasil panennya yang berakibat persediaan beras di penjual berkurang. Sebaliknya, saat harga beras mahal maka kansumen akan menjerit. Bulog berperan dalam menstabilkan persediaan beras. Jika persediaan beras cukup maka harga tidak akan naik ataupun turun.

Campur tangan pemerintah dalam ekonomi tentang beras antara lain dilakukan melalui lembaga pangan yang bertugas melaksanakan kebijakan pemerintah yang menyangkut aspek pra produksi, proses produksi, serta pasca produksi. Bulog dibentuk untuk mengendalikan stabilitas harga dan penyediaan bahan pokok, terutama pada tingkat konsumen (Saifullah, 2001).

Upaya pengaktifan peran bulog penting untuk menstabilkan harga bahan pangan dan melindungi kepentingan petani sebagai produsen yang rentan terhadap fluktuasi harga. Impor bahan pangan pada umumnya dapat menstabilkan namun dalam jangka yang pendek dan ini akan berakibat pada petani produsen. Selain bulog, adanya operasi pasar dan operasi stabilisasi harga dapat dilakukan untuk menekan fluktuasi harga beras dengan melibatkan pedagang.

\section{c. Risiko Teknologi}

Adopsi menurut Nagy (2010) dalam konteks penggunaan teknologi baru oleh organisasi adalah organisasi melakukan pembelian dan menerapkan teknologi baru tersebut. Jadi dapat dikatakan bahwa adopsi adalah serangkaian tahapan, kesadaran, niat individu yang sampai pada tindakan 
menerima suatu objek dan menggunakan teknologi tersebut.

Persepsi Petani Tentang Masa Depan

Untuk menghindari kerugian dalam mengadopsi teknologi baru, petani harus mengeenal teknologi tersebut. Pelatihan khusus terkait teknologi baru dapat memudahkan petani dalam pengambilan keputusan.

\section{d. Risiko Sosial dan Hukum}

Pembatasan subsidi dan penyimpangan mengakibatkan ketidakpastian adanya subsidi pupuk maupun benih. Hal ini mempengaruhi pengeluaran petani jika tidak ada subsidi. Ketika subsidi benih dan pupuk dibatasi, maka solusi yang bisa ditempuh adalah petani menggunakan biaya dari tabungan atau memanfaatkan PUAP di tingkat desa untuk memperoleh modal.

Sesuai Surat Keputusan Menperindag No. 70/MPP/Kep/2/2003 tentang Pengadaan dan Penyaluran Pupuk Bersubsidi untuk Sektor Pertanian dalam rangka mendukung ketahanan pangan nasional sangat diperlukan dukungan penyediaan pupuk yang memenuhi prinsip 6 tepat yaitu : jenis, jumlah, harga, tempat, waktu dan mutu.

Petani berpikiran tentang keinginan di masa depan seperti:

1. Produksi meningkat

Meningkatnya produksi merupakan keinginan semua petani yang menjadi sampel peneliti. Ketika petani memperoleh hasil yang maksimal maka kebutuhan hidup petani dapat tercukupi. Petani mulai tekun dalam merawat dengan cara mengurangi adanya populasi hama yang sampai saat ini tetap menjadi keluhan para petani dan mencoba menaikkan hasilnya dengan cara penanaman dengan sistem jajar legowo. Sistem jajar legowo adalah suatu rekayasa teknologi untuk mendapatkan populasi tanaman lebih dari 160.000 per hektar. Penerapan jajar legowo selain meningkatkan populasi pertanaman tetapi juga mampu berfotosintesis dengan baik karena terdapat lorong-lorong sehingga sinar matahari dapat masuk ke tanaman (Balai Besar Penelitian Tanaman Padi, 2016b).

2. Menambah luas lahan hidroponik Hidroponik merupakan sistem budidaya tanpa menggunakan media 
tanam tanah, melainkan air. Hidroponik cocok diterapkan pada daerah sempit. Hidroponik dapat dilakukan di teras, samping, maupun di atas rumah.

\section{KESIMPULAN DAN SARAN}

\section{Kesimpulan}

Risiko usahatani yang dialami petani meliputi risiko produksi, resiko harga, risiko teknologi dan risiko sosial dan hukum.

Upaya petani mengatasi risiko produksi yaitu, pembuatan embung, pengendalian hama dan pelaksanaan pola tanam bergilir. Saat terjadi risiko harga peran bulog sangat dibutuhkan. Risiko teknologi diatasi dengan identifikasi teknologi yang akan diadopsi. Risiko sosial dan hukum terkait pembatasan subsidi benih dan pupuk diatasi dengan penggunaan tabungan hasil dari pekerjaan lain selain bertani dan dapat memanfaatkan PUAP.

$$
\text { Harapan petani dalam }
$$

berusahatani yaitu: 1) meningkatkan produksi dengan menambah luas lahan tanaman sayur dan hidroponik, 2) berusaha ternak ikan, ternak sapi dan ayam, 3) pelatihan bisnis, pendanaan (kredit modal), teknologi, dan pasar bagi para pemuda dalam sektor pertanian bernilai ekonomi tinggi pada luas lahan yang relatif tidak luas.

\section{Saran}

Petani supaya memaksimalkan produksi pada saat musim penghujan dengan varietas yang tahan akan genangan air. Petani supaya memperhatikan kondisi pasar dan pertimbangan biaya yang dikeluarkan. Penggunaan pupuk dan pestisida harus sesuai dengan dosis, menggunakan pupuk organik dan menanam padi dengan sistem jajar legowo.

Bagi peneliti, perlu dilakukan penelitian multi lokasi.

\section{DAFTAR PUSTAKA}

Balai Besar Penelitian Tanaman Padi. 2016a. Waspada Serangan Hama Tanaman Padi diMusim Hujan. Kementrian Pertanian.

Balai Besar Penelitian Tanaman Padi. 2016b. Prinsip dan Populasi Sistem Tanam Jajarlegowo. Kementrian Pertanian.

Balai Besar Penelitian Tanaman Padi. 2017. Bahan Pestisida Nabati Ramah Lingkungan. Kementrian Pertanian.

Balitbangtan. 2003. Embung, Sedikit Solusi Mengatasi Kekeringan. Kementrian Pertanian Republik Indonesia. 
Djohanputro, B. 2008. Manajemen Risiko Korporat. Jakarta: PPM. Manajemen.

Hernanto, F. 1991. Ilmu Usaha Tani. Jakarta: Penebar Swadaya.

Hubeis dan Vitayala, A. 2007. Expectacy Teori pada Studi Kasus: Pelaksanaan Training Sebagai Media Untuk Mewujudkan Harapan Karyawan di Suatu Perusahaan Jasa. Program Pascasarjana Manajemen dan Bisnis Institut Pertanian Bogor.

Nagy, D. 2010. Understanding Organizational Adoption Theories Thought the Adoption of Dirsubtive Innovation: Five Cases of Open Source Software.

Graduate Theses and Dissertation. University of South Florida.

Nalbantis, I, and Tsakiris, G. 2008. Assessment of Hydrological Drought Revisited. Water Resources Management.

Nawawi, D. 2005. Metode Penelitian Sosial. Yogyakarta: Gadjah Mada Offset.

Rahim, Abdul, dan Diah Retno Dwi Hastuti. 2007. Ekonomika Pertanian (Pengantar, Teori dan Kasus). Penebar Swadaya, Jakarta.

Saifullah, A. 2001. Peran Bulog Dalam Kebijakan Perberasan Nasional. Jakarta.

Surat Keputusan Menperindag No. 70/MPP/Kep/2/2003.
Tjeppy, D. S. 2017. Jurnal Litbang Pertanian. 26(2). 